\title{
Sediment organic carbon burial in agriculturally eutrophic impoundments over the last century
}

\author{
J. A. Downing, ${ }^{1,2}$ J. J. Cole, ${ }^{3}$ J. J. Middelburg, ${ }^{4}$ R. G. Striegl, ${ }^{5}$ C. M. Duarte, ${ }^{6}$ \\ P. Kortelainen, ${ }^{7}$ Y. T. Prairie, ${ }^{8}$ and K. A. Laube ${ }^{9}$ \\ Received 3 October 2006; revised 13 June 2007; accepted 14 September 2007; published 15 February 2008.
}

[1] We estimated organic carbon (OC) burial over the past century in 40 impoundments in one of the most intensively agricultural regions of the world. The volume of sediment deposited per unit time varied as a function of lake and watershed size, but smaller impoundments had greater deposition and accumulation rates per unit area. Annual water storage losses varied from $0.1-20 \%$ and were negatively correlated with impoundment size. Estimated sediment OC content was greatest in lakes with low ratios of watershed to impoundment area. Sediment OC burial rates were higher than those assumed for fertile impoundments by previous studies and were much higher than those measured in natural lakes. OC burial ranged from a high of $17,000 \mathrm{~g} \mathrm{C} \mathrm{m}^{-2} \mathrm{a}^{-1}$ to a low of $148 \mathrm{~g} \mathrm{C} \mathrm{m}^{-2} \mathrm{a}^{-1}$ and was significantly greater in small impoundments than large ones. The OC buried in these lakes originates in both autochthonous and allochthonous production. These analyses suggest that $\mathrm{OC}$ sequestration in moderate to large impoundments may be double the rate assumed in previous analyses. Extrapolation suggests that they may bury 4 times as much carbon (C) as the world's oceans. The world's farm ponds alone may bury more OC than the oceans and $33 \%$ as much as the world's rivers deliver to the sea.

Citation: Downing, J. A., J. J. Cole, J. J. Middelburg, R. G. Striegl, C. M. Duarte, P. Kortelainen, Y. T. Prairie, and K. A. Laube (2008), Sediment organic carbon burial in agriculturally eutrophic impoundments over the last century, Global Biogeochem. Cycles, 22, GB1018, doi:10.1029/2006GB002854.

\section{Introduction}

[2] Lakes and impoundments are depositional environments. The material that accumulates in the sediments of these water bodies can be airborne deposits imported from outside the watershed, air- plus water-borne deposits imported from inside the watershed (allochthonous inputs), or created by biological or chemical processes that occur within the water body (autochthonous inputs). For organic carbon (OC) the ultimate source is past and present primary production, either in the watershed or in the water body. For either source the OC buried in the sediments of lakes or reservoirs represents short- to long-term-scale sequestration

\footnotetext{
${ }^{1}$ Department of Ecology, Evolution, and Organismal Biology, Iowa State University, Ames, Iowa, USA.

${ }^{2}$ On sabbatical at Instituto Mediterraneo de Estudios Avanzados, Esporles, Spain.

${ }^{3}$ Institute of Ecosystem Studies, Millbrook, New York, USA.

${ }^{4}$ Centre for Estuarine and Marine Ecology, Netherlands Institute of Ecology, Yerseke, Netherlands.

${ }^{5}$ United States Geological Survey, Denver, Colorado, USA.

${ }^{6}$ Institut Mediterrani d'Estudis Avançats (CSIC-UIB), Esporles, Spain.

${ }^{7}$ Finnish Environment Institute, Helsinki, Finland.

${ }^{8}$ Département des Sciences biologiques, Université du Québec à Montréal, Montreal, Quebec, Canada.

${ }^{9}$ Laube Engineering LLC, Greeley, Colorado, USA.

Copyright 2008 by the American Geophysical Union. 0886-6236/08/2006GB002854
}

of atmospheric $\mathrm{CO}_{2}$. Globally, this burial of $\mathrm{OC}$ in the sediments of natural lakes has been estimated in the range of 30 to $70 \mathrm{Tg} \mathrm{C} \mathrm{a}^{-1}$ [Dean and Gorham, 1998; Einsele et al., 2001; Mulholland and Elwood, 1982; Stallard, 1998]. The burial in impoundments is thought to be much larger (150 to $220 \mathrm{Tg} \mathrm{C} \mathrm{a}{ }^{-1}$ ) [Mulholland and Elwood, 1982; Stallard, 1998]. While these rates are modest in comparison with the current total storage of organic carbon (C) terrestrially (1000 to $4000 \mathrm{Tg} \mathrm{C} \mathrm{a}^{-1}$ ) [Pacala et al., 2001; Randerson et al., 2002; Schimel et al., 2001], they are comparable to the storage of OC in the sediments of the global ocean (about 120-240 Tg C a ${ }^{-1}$ ) [Duarte et al., 2004; Meybeck, 1993; Sundquist, 2003]. Further, the annual amount of organic $\mathrm{C}$ stored in lakes and reservoirs is of comparable magnitude to the delivery of $\mathrm{OC}$ by rivers to the ocean, about $400 \mathrm{Tg} \mathrm{C} \mathrm{a}^{-1}$ [Meybeck, 1993; Probst, 2005].

[3] The OC burial in impoundments is of particular interest because they are manmade structures. Whatever the ultimate source, the OC now stored in them met a different fate prior to impoundment. Further, the global estimates of impoundment OC storage are based on a limited suite of impoundment types. Missing from these estimates are major classes of very abundant, small impoundments that are also agriculturally impacted. These systems receive agricultural fertilizers that enhance autochthonous primary production. Further, agricultural lands tend to have carbon-rich soils that, when tilled, are very suscep- 
tible to rapid erosion. Thus these impoundments might be expected to have much higher rates of sediment OC accumulation than those in regions where agriculture does not dominate.

[4] There are several other unknowns concerning currently accepted estimates of global sediment organic carbon burial in reservoirs and impoundments. First, recent reviews [e.g., Dean and Gorham, 1998; Stallard, 1998] have used the same cited sources [Mulholland and Elwood, 1982] that are strongly influenced by data on sediment deposition in impoundments in certain regions of the United States [Dendy and Champion, 1978]. These data were collected using a variety of unstandardized methods of unknown accuracy collected by diverse government agencies for divergent purposes, were assembled to analyze changes in impoundment water storage capacity, not necessarily mass accumulation, and, following common practice [e.g., Ritchie, 1989], inferred sediment dry bulk density (dry mass per unit volume) as average values from other studies [Dendy, 1968; Dendy and Champion, 1978] or simply as estimates of unspecified provenance. Estimates of volume and mass burial may thus be inaccurate. Further, many current published studies have not made direct or indirect estimates of sediment OC content or organic matter in the systems analyzed but have instead computed OC burial assuming an unweighted average sediment OC composition found in other studies [e.g., Ritchie, 1989].

[5] The objective of this study was to estimate sediment $\mathrm{OC}$ deposition in a variety of impoundments in an agricultural region using estimates of sediment volume accumulation, dry bulk density, and sediment organic matter content estimated within those same ecosystems. This approach allows approximation of sediment OC burial over different intervals during the past century.

\section{Methods}

[6] We calculated sediment burial in 40 water bodies in the U.S. state of Iowa. The state of Iowa is one of the most productive agricultural areas in the world [Downing et al., 1999], in which $90 \%$ of the total land area is under some form of agricultural use [Arbuckle and Downing, 2001]. The impoundments we studied varied in area from 0.008 to 42 $\mathrm{km}^{2}$ (Table 1). This size of impoundment is extremely abundant in the world, covering $>75,000 \mathrm{~km}^{2}$ globally [Downing et al., 2006], or about 30\% of the Earth's 0.26 million $\mathrm{km}^{2}$ of impoundments [Downing et al., 2006]. There are about 80,000 small impoundments $\left(<0.02 \mathrm{~km}^{2}\right)$ in the state of Iowa alone.

[7] We calculated the sediment accumulation rate in these impoundments directly by comparing series of sequential, repeated bathymetric surveys performed in different years. The loss of water storage volume between bathymetric surveys made in different years was considered to be the net sediment accrual over that time period. This method is the most accurate way of determining whole-lake sedimentation rates [Holeman, 1975; Morris and Fan, 1998], because it does not require upscaling from small-area sediment deposition records [e.g., Dendy and Champion, 1978] that can be biased by sediment focusing or nonrepresentative sampling.
[8] Bathymetric surveys were performed through ice with sounding rods, from boats with sounding rods, and using sonar from boats. Surveys using sounding rods determined horizontal position using standard surveying techniques. Sonar bathymetry was performed by sounding transects across predetermined courses. All depth data were adjusted to elevation benchmarks (usually the elevation of the lake spillway) to allow direct comparison. All maps were analyzed through planimetry to determine lake volume. Sediment accumulation was determined across the entire impoundment by calculating the differences between volumes and dividing by the number of years between bathymetric surveys. Bathymetric surveys were performed from 1913 to 1990 although most of the averages of first and last survey dates were between 1940 and 1960 (Table 1). Where more than two bathymetric surveys were performed on a given water body, sedimentation rates over the longest possible time period were calculated.

[9] Sediment mass accumulation in 25 of these impoundments was determined as the product of total sediment volume accumulated and sediment dry bulk density (kg dry mass $\mathrm{m}^{-3}$ ). Determinations of sediment dry bulk density were made following standard methods [Rausch and Heinnemann, 1984] between 1978 and 1990 at many sites across water bodies, distributed to represent principal areas of sediment deposition. Sediment samples were extracted by hydraulically pushing Shelby tubes $(7.6 \mathrm{~cm}$ diameter) into the sediment to the approximate depth of sediment deposition over the period of the bathymetric surveys. Cores were checked for compaction by noting differences between sediment core length and depth of hydraulic penetration [Schaefer, 1981]. Core samples were taken principally in the upper $60 \mathrm{~cm}$ of sediment at many sites in each lake [Iowa State Planning Board (ISPB), 1935; Lane and Koelzer, 1943; Laube, 1991]. Sediment core samples were divided into approximately $10 \mathrm{~cm}$ segments. Dimensions of segments of sediment were measured and volumes were calculated. Samples were oven-dried to constant mass [Julien, 1995] and dry bulk density calculated following standard methods and definitions [Julien, 1995; Spangler and Handy, 1982; Vanoni, 1975]. Particle sizes were also estimated on these sediment samples using the pipette method recommended by Vanoni [1975]. This was done to confirm dry bulk densities because these are often closely related to particle size distributions. The samples were dispersed with an air jet for $5 \mathrm{~min}$ rather through shaking overnight [Hallberg, 1978; Schaefer, 1981].

[10] Sediment organic carbon concentration per unit dry mass was estimated by loss on ignition [Heiri et al., 2001] in 2005 in 16 of these same lakes. Sediment samples were sampled with a box corer from the upper $50 \mathrm{~cm}$ from the part of the lake representing the area of most rapid deposition [Morris and Fan, 1998] and that deposited over the span of surveys. Replicate samples were homogenized and subsampled before a known volume of sediment was weighed, dried to constant mass $\left(60^{\circ} \mathrm{C}\right)$, reweighed, then ashed $\left(550^{\circ} \mathrm{C}\right.$ for $\left.2 \mathrm{~h}\right)$, cooled in a dessicator, and reweighed. Loss on ignition (LOI) divided by 2.13 was used as an approximation of sediment organic carbon content because work performed within $50-200 \mathrm{~km}$ of our sites [Dean and 
Table 1. Data Used to Analyze Organic Carbon (OC) Deposition

\begin{tabular}{|c|c|c|c|c|c|c|c|c|c|c|}
\hline Lake $^{\mathrm{a}}$ & $\begin{array}{l}\text { Earliest } \\
\text { Survey } \\
\end{array}$ & $\begin{array}{l}\text { Latest } \\
\text { Survey } \\
\end{array}$ & $\begin{array}{c}\text { Lake Area, } \\
\mathrm{km}^{2}\end{array}$ & $\begin{array}{l}\text { Watershed } \\
\text { Area, } \mathrm{km}^{2}\end{array}$ & $\begin{array}{c}\text { Watershed } \\
\text { Area: } \\
\text { Lake Area }\end{array}$ & $\begin{array}{c}\text { Sediment } \\
\text { Deposition, } \\
\mathrm{m}^{3} \mathrm{a}^{-1}\end{array}$ & $\begin{array}{c}\text { Annual } \\
\text { Water } \\
\text { Volume } \\
\text { Loss, \% a } \mathrm{a}^{-1} \\
\end{array}$ & $\begin{array}{c}\text { Sediment } \\
\text { Bulk } \\
\text { Density } \\
\text { Dry, } \\
\mathrm{kg} \mathrm{m}^{-3} \\
\end{array}$ & $\begin{array}{l}\text { Sediment } \\
\text { Loss on } \\
\text { Ignition, } \\
\text { Fraction of } \\
\text { Dry Mass } \\
\end{array}$ & $\begin{array}{l}\text { OC Burial, } \\
\mathrm{g} \mathrm{m}^{-2} \mathrm{a}^{-1} \\
\end{array}$ \\
\hline Allerton Reservoir & 1913 & 1939 & 0.414 & 12.5 & 30.1 & 5320 & 0.8 & & 0.097 & \\
\hline Backbone Lake & 1934 & 1949 & 0.506 & 316.7 & 625.8 & 11400 & 1.5 & 1203 & 0.086 & 1089 \\
\hline Barney Mundt & 1944 & 1952 & 0.016 & 0.9 & 55.2 & 1950 & 3.8 & 884 & 0.093 & 4864 \\
\hline Beeds Lake & 1935 & 1979 & 0.429 & 81.8 & 191.0 & 8130 & 0.6 & & 0.101 & \\
\hline Black Hawk Lake & 1916 & 1935 & 3.230 & 48.7 & 15.1 & 41400 & 0.8 & 713 & $\overline{0.098}$ & 419 \\
\hline Bloomfield & 1937 & 1951 & 0.311 & 5.5 & 17.7 & 5720 & 0.5 & & 0.096 & \\
\hline C. A. Stiles & 1940 & 1953 & 0.054 & 1.5 & 27.2 & 1040 & 1.1 & 839 & 0.094 & 702 \\
\hline Centerville Reservoir 2 & 1926 & 1937 & 0.207 & 6.8 & 32.8 & 6850 & 0.5 & & 0.095 & \\
\hline Charles Fienhold & 1945 & 1949 & 0.008 & 1.1 & 141.2 & 3070 & 19.8 & 1011 & 0.093 & 17392 \\
\hline Clear Lake & 1935 & 1971 & 14.743 & 35.5 & 2.4 & 55500 & 0.1 & & 0.235 & \\
\hline CM ST P\&P RR Reservoir & 1903 & 1918 & 0.052 & 6.5 & 126.0 & 1480 & 2.8 & & $\overline{0.093}$ & \\
\hline Coralville Reservoir & 1958 & 1975 & 19.830 & 7900.0 & 398.4 & 992000 & 1.5 & 681 & 0.009 & 148 \\
\hline Don Williams Lake & 1974 & 1980 & 0.615 & 83.7 & 136.0 & 17900 & 0.6 & 554 & $\overline{0.100}$ & 755 \\
\hline Fairfield 3 & 1927 & 1953 & 0.162 & 7.6 & 46.7 & 3420 & 1.3 & 827 & $\overline{0.094}$ & 773 \\
\hline Farmer's Ditch & 1941 & 1945 & 3.885 & 55.4 & 14.3 & 130000 & 15.6 & 1094 & 0.130 & 2227 \\
\hline Five Island Lake & 1935 & 1970 & 4.011 & 34.1 & 8.5 & 26400 & 0.5 & & 0.169 & \\
\hline Fred Hollrah & 1944 & 1949 & 0.010 & 0.6 & 53.1 & 1670 & 7.1 & 934 & $\overline{0.093}$ & 6537 \\
\hline Honey Creek F-1 & 1955 & 1961 & 0.034 & 3.1 & 92.3 & 1190 & 0.5 & 1057 & 0.093 & 1640 \\
\hline Jones Creek Reservoir & 1942 & 1953 & 0.078 & 5.8 & 74.3 & 6230 & 2.0 & 878 & 0.094 & 3093 \\
\hline Lake Icaria & 1976 & 1986 & 2.833 & 72.8 & 25.7 & 212000 & 2.3 & & 0.090 & \\
\hline Lake Iowa & 1978 & 1988 & 0.340 & 5.4 & 15.9 & 5670 & 0.5 & & $\overline{0.096}$ & \\
\hline Lake John Deere & 1979 & 1988 & 0.050 & 3.4 & 68.4 & 6030 & 3.0 & & 0.093 & \\
\hline Lake Panorama & 1970 & 1980 & 5.666 & 1139.6 & 201.1 & 657000 & 2.8 & 1202 & 0.107 & 6987 \\
\hline Lake of Three Fires & 1936 & 1950 & 0.393 & 15.5 & 39.3 & 33700 & 2.2 & & 0.085 & \\
\hline Lake Wapello & 1937 & 1982 & 1.153 & 20.2 & 17.5 & 16400 & 0.3 & 521 & $\overline{0.146}$ & 508 \\
\hline Lower Pine Lake & 1924 & 1932 & 0.263 & 39.2 & 149.0 & 28900 & 3.2 & 1256 & 0.089 & 5771 \\
\hline Max Miller 5 & 1941 & 1952 & 0.013 & 0.6 & 45.4 & 1410 & 2.2 & 1179 & $\overline{0.093}$ & 5593 \\
\hline Prairie Rose Lake & 1971 & 1985 & 0.882 & 18.5 & 21.0 & 43900 & 1.8 & 1474 & 0.083 & 2862 \\
\hline Red Rock Reservoir & 1977 & 1984 & 42.089 & 15695.9 & 372.9 & 2240000 & 2.9 & & $\overline{0.070}$ & \\
\hline Silver Lake & 1935 & 1973 & 2.699 & 32.4 & 12.0 & 14400 & 0.3 & & $\overline{0.122}$ & \\
\hline Springbrook Lake & 1936 & 1980 & 0.069 & 4.9 & 71.3 & 2010 & 0.9 & 767 & $\overline{0.105}$ & 1111 \\
\hline Swan Lake & 1935 & 1980 & 0.526 & 3.1 & 6.0 & 3950 & 0.7 & 881 & $\overline{0.114}$ & 353 \\
\hline Theobold C & 1949 & 1952 & 0.041 & 0.6 & 14.6 & 1420 & 3.1 & 1088 & $\overline{0.093}$ & 1635 \\
\hline Theobold Main & 1949 & 1952 & 0.106 & 1.1 & 10.8 & 5230 & 4.1 & 1158 & 0.094 & 2519 \\
\hline Tracy North & 1939 & 1953 & 0.018 & 0.6 & 34.0 & 1010 & 1.7 & 868 & 0.093 & 2122 \\
\hline Tuttle Lake & 1935 & 1973 & 11.396 & 444.4 & 39.0 & 104000 & 0.7 & & 0.192 & \\
\hline Union Grove Lake & 1936 & 1950 & 0.478 & 27.9 & 58.4 & 14800 & 1.4 & 686 & 0.097 & 958 \\
\hline Upper Pine Lake & 1934 & 1990 & 0.239 & 35.7 & 149.6 & 12600 & 1.6 & & $\overline{0.094}$ & \\
\hline Wilbur Meyer & 1944 & 1952 & 0.010 & 0.8 & 73.0 & 1490 & 2.8 & 900 & 0.093 & 5647 \\
\hline William Esbeck & 1944 & 1949 & 0.010 & 0.5 & 50.9 & 1110 & 7.1 & 900 & 0.093 & 4201 \\
\hline
\end{tabular}

${ }^{a}$ Lake names either refer to known geographic place names or the names of owners of impoundments.

bItalicized data were predicted from equation (3); underlined data are observed loss on ignition (LOI) values.

Gorham, 1976; Dean, 1974] with similar lake water cation chemistry [Dean, 1999] has shown that this method provides estimates of $\mathrm{C}$ content of lake sediments that are comparable in precision and accuracy to other methods across a range of loss on ignition from $6-56 \%$.

\section{Results}

[11] Sediment burial in these impoundments was substantial but in line with water storage losses seen in similar impoundments in other agricultural areas. Annual water storage volume loss or its equivalent sediment deposition $\left(\mathrm{S} ; \mathrm{m}^{3} \mathrm{a}^{-1}\right)$ increased with the size of the watershed (Figure 1). Multiple regression, using values log transformed to linearize relationships, showed that storage loss and sediment deposition rate varied as

$$
\mathrm{S}=5682 \mathrm{~A}^{0.3609} \mathrm{~W}^{0.4155}
$$

$\left(R^{2}=0.87, n=40, p<0.001\right)$ where A is the lake area $\left(\mathrm{km}^{2}\right)$, W is the watershed area $\left(\mathrm{km}^{2}\right)$, and partial effects of A and W were both statistically significant $(p<0.01)$. Annual water storage loss, expressed as a percentage of the volume of the water body, was as low as $0.1-3 \%$ in the largest impoundments but $>2 \%$ in the smallest ones (Figure 2). The relationship between percent water storage loss and impoundment size was statistically significant $(p=0.009)$ but weak $\left(r^{2}=0.17, n=40\right)$.

[12] Sediment accumulation rates $\left(\omega ; \mathrm{cm} \mathrm{a}^{-1}\right)$, calculated as sediment deposition (S) divided by the area of the impoundment, varied from 0.4 to $39.4 \mathrm{~cm} \mathrm{a}^{-1}$ (mean $\left.5.9 \mathrm{~cm} \mathrm{a}^{-1}\right)$. Sediment accumulation varied significantly as

$$
\omega=0.594 \mathrm{~A}^{-0.6768} \mathrm{~W}^{0.3491} \mathrm{AW}^{0.1035}
$$

$\left(r^{2}=0.60, n=40, p<0.001\right)$, where the partial effects of A, $\mathrm{W}$, and AW were statistically significant $(\mathrm{p}<0.05)$ and are 


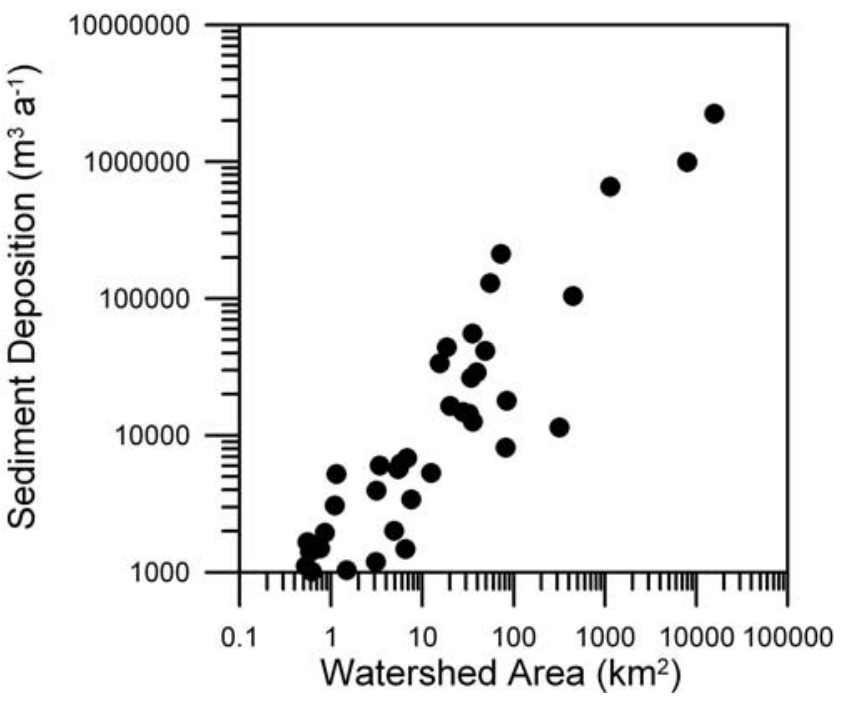

Figure 1. Relationship between the volume of sediment deposited annually in impoundments and the size of the watershed. Sediment deposition was measured as annual storage loss estimated from repeated bathymetric surveys.

listed in order of their statistical strength. Impoundment area had the strongest influence on $\omega$ (Figure 3 ).

[13] The sediment dry bulk density varied substantially among lakes and was roughly correlated with the rate of fractional annual water storage loss (Figure 4) as well as with $\omega$. Dry bulk density was correlated with particle size distributions in the expected way [Lane and Koelzer, 1943]. Dry bulk density varied from about $500 \mathrm{~kg} \mathrm{~m}^{-3}$, which is about 4 times the dry bulk density of peat [Schlotzhauer and

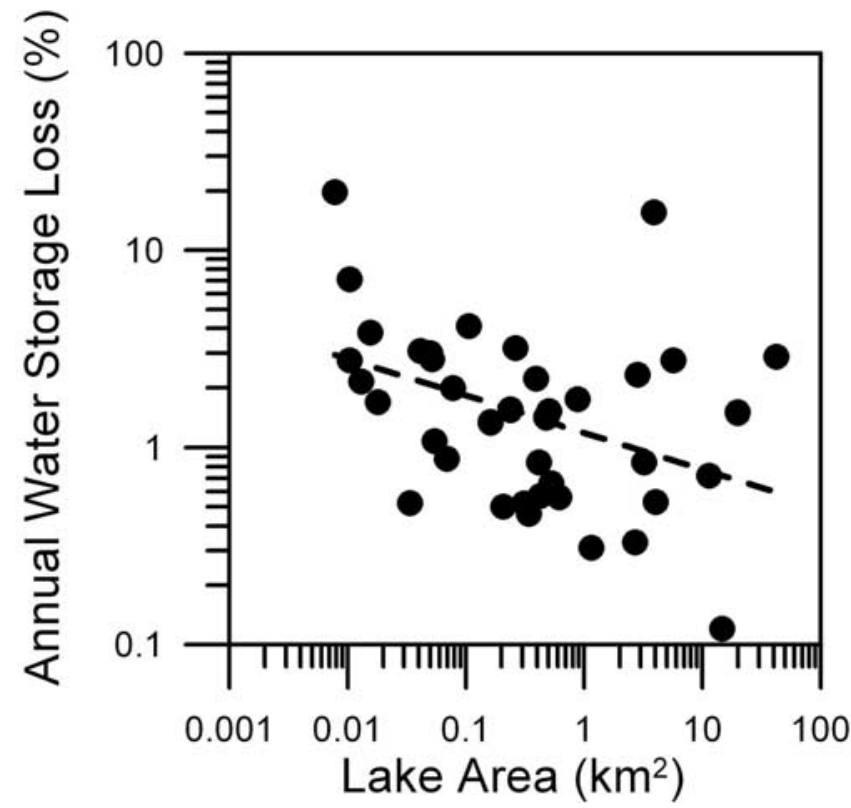

Figure 2. Relationship between the annual fractional loss of lake water volume and lake area. Dashed line is the fitted least squares regression $\left(r^{2}=0.17, n=40, p=0.009\right)$.

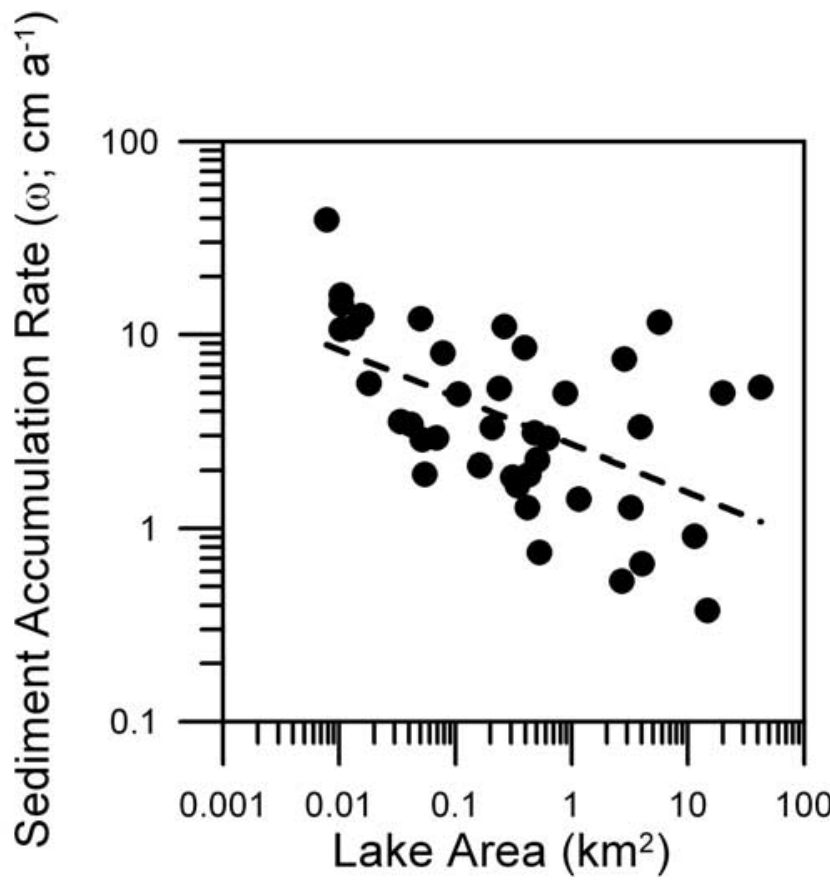

Figure 3. Relationship between sediment accumulation rate and the area of lakes. Dashed line is the fitted least squares regression $\left(r^{2}=0.30, n=40, p=0.003\right)$.

Price, 1999], or about the dry bulk density of dry corn and wheat seeds [Trabelsi et al., 2001], to $1500 \mathrm{~kg} \mathrm{~m}^{-3}$, which is about the bulk density of sand or firmly packed soils [Henderson et al., 1988; McNabb et al., 2001; Morris and

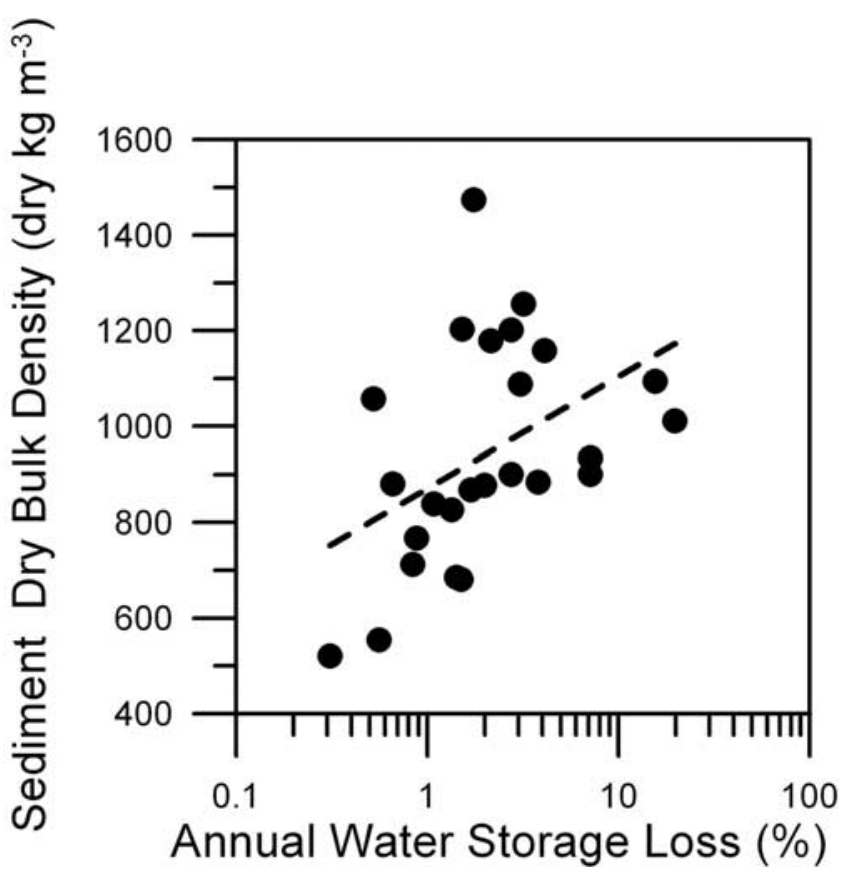

Figure 4. Relationship between the amount of dry matter per unit volume of sediments (bulk density) and the annual storage loss of lakes. Dashed line indicates the fitted least squares regression $\left(r^{2}=0.20, n=25, p=0.025\right)$. 


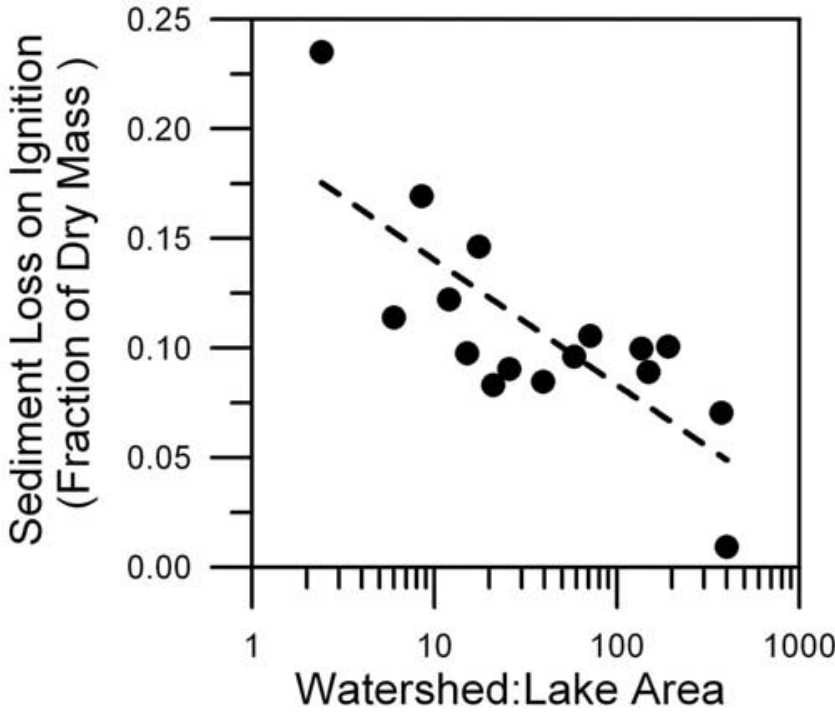

Figure 5. Sediment dry mass loss on ignition (LOI) expressed as fraction of dry sediment mass related to the ratio of watershed to lake area. Joint, independent influences of watershed and lake area are implied by equation (3). Dashed line is the fitted least squares, semilog linear regression $\left(r^{2}=0.60, n=16, p<0.0005\right)$.

Fan, 1998]. The average dry bulk density observed in these lake sediments $\left(942 \mathrm{~kg} \mathrm{~m}^{-3}\right)$ was only about $50 \%$ lower than the dry bulk densities of normal terrestrial soils [Calhoun et al., 2001]. The average and range of our dry bulk densities were comparable to those found for reservoirs and impoundments $\left(1100 \mathrm{~kg} \mathrm{~m}^{-3}\right.$; range $\left.320-2000\right)$ by Dendy and Champion [1978] and similar to those typifying dry bulk densities of materials found permanently submerged in impoundments [Stall, 1981].

[14] Sediment LOI varied substantially among the 16 impoundments on which we measured it (Table 1). The highest LOI was found in Clear Lake, a eutrophic, impounded natural lake with a small watershed, while the lowest LOI was found in Coralville Lake, a large flood control impoundment with a very large watershed. If sediment carbon is $47 \%$ of loss on ignition, as was found for lakes near our sites [Dean, 1999; Dean and Gorham, 1976; Dean, 1974], the accumulating sediments we analyzed were composed of from $0.5 \%$ to $11 \%$ OC. Further, using standard least squares multiple regression analysis, we found that measured LOI, expressed as a fraction of sediment dry mass, varied systematically with both lake size and watershed size as

$$
\begin{aligned}
\mathrm{LOI}= & 0.093+(0.0096 \mathrm{~A})-\left(4.2 \times 10^{-5} \mathrm{~W}\right) \\
& +\left(3.497 \times 10^{-7} \mathrm{AW}\right)
\end{aligned}
$$

$\left(r^{2}=0.84, n=16, p<0.001\right)$ where all variables are as in equation (1) and all regression coefficients were statistically significant $(p<0.05)$. Because of the joint influence of lake and watershed area on LOI, sediment OC also varied systematically with the ratio of the watershed area to the area of the lake. LOI as a fraction of dry mass of sediment is shown plotted in Figure 5 for the 16 impoundments for which we made direct estimates. Because some lakes were on private property or were recently drained or filled with soil, equation (3) was used to predict loss on ignition in impoundments where it was not estimated by direct means (italics on Table 1). The average LOI in the impoundments we studied was about $10.3 \%$, which corresponds to a sediment OC content of about $4.8 \%$, assuming that sediment OC is approximately $47 \%$ of LOI [Dean, 1974].

[15] We approximated sediment OC burial using direct measures of hydrographic change and dry bulk density from 25 impoundments and approximations of sediment OC from direct measures of LOI on 16 impoundments and predicted LOI (equation (3)) for nine of them. Estimated sediment OC burial $\left(\mathrm{B} ; \mathrm{g} \mathrm{m}^{-2} \mathrm{a}^{-1}\right.$ ) varied from only about $150 \mathrm{~g} \mathrm{~m}^{-2} \mathrm{a}^{-1}$ in the large flood control Coralville Reservoir to more than $17,000 \mathrm{~g} \mathrm{~m}^{-2} \mathrm{a}^{-1}$ in the tiny $\left(0.008 \mathrm{~km}^{2}\right)$ impoundment owned by farmer Charles Fienhold (Table 1). Organic carbon burial was generally high in small impoundments, declining exponentially in large ones (Figure 6). The data fit a power function:

$$
\mathrm{B}=1060 \mathrm{~A}^{-0.298}
$$

$\left(r^{2}=0.35, n=25, p=0.002\right)$, suggesting a rapid decline in carbon burial in large impoundments. Multiple regression indicated that there was no significant trend in burial rates with the median year of bathymetric surveys $(p>0.05)$.

\section{Discussion}

[16] Sediment deposition rate increased with both impoundment area and watershed size (equation (1)). Water storage loss rates seen in this study were similar to those

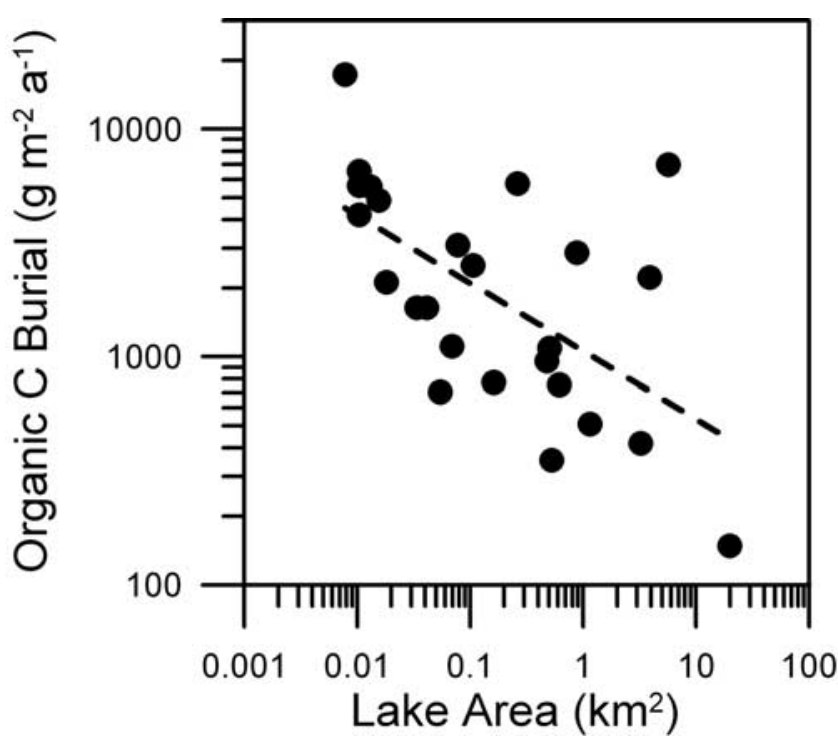

Figure 6. Sediment organic carbon (OC) burial in impoundments measured in this study. Dashed line is the least squares regression between carbon burial and lake size $\left(r^{2}=0.35, n=25, p=0.002\right)$. 
seen in other studies of sedimentation in impoundments [Dendy, 1968; McHenry, 1974]. The relationship in equation (1) suggests that total sediment burial approximately doubles with a tenfold increase in impoundment size and increases slightly more rapidly with increased watershed size. Since sediment deposition rate per unit impoundment area declined as $\propto \mathrm{A}^{-0.6391}$ (equation (1)), and sediment accumulation $\left(\omega ; \mathrm{cm} \mathrm{a}^{-1}\right)$ declined as $\propto \mathrm{A}^{-0.5733}$ (equation (2)), equations (1) and (2) imply an approximately fourfold reduction in areal sediment deposition $\left(\mathrm{m}^{3}\right)$ and accumulation $\left(\omega ; \mathrm{cm} \mathrm{a}^{-1}\right)$ for a tenfold increase in lake area. This finding agrees with others who have suggested greatest burial of erosional materials in small impoundments [Smith et al., 2002]. Because the exponent describing the effect of watershed size in equations (1) and (2) is $<1$, large watersheds have smaller exports of materials, per unit area, than do smaller ones. This could occur because of the large diversity of terrain encountered in large watersheds, such that agricultural sediment delivery may be delayed through sequestration in wetlands, bottomlands, and intermediating water bodies, before it is delivered downstream. This well known relationship between watershed size and sediment delivery varies regionally with geomorphic history and regional topography [Renwick, 1996] and is thought to arise because of conveyance losses, low slope, low channel gradients, increased opportunities for deposition, and the likelihood that runoff originates in an area smaller than the whole watershed in large watersheds [Walling, 1983]. Small impoundments, however, accumulate a much greater volume of sediment per unit time and area than do larger ones. This may be due to the burial of shore erosional materials and trophic conditions in small impoundments that favor conservation of organic sediment material as well as higher sediment yields in the small watersheds of small impoundments [Walling, 1983].

[17] The dry bulk density and the OC content of sediment deposits implied by LOI measurements varied much more than expected from previous analyses of OC burial. For example, the most frequently cited data on OC burial in impoundments [Mulholland, 1981; Mulholland and Elwood, 1982] used measured, volumetric sediment deposition rates converted to $\mathrm{OC}$ burial estimates assuming a dry bulk density of $1000 \mathrm{~kg} \mathrm{~m}^{-3}$ and a sediment OC concentration of $1.5 \%$. Ritchie [1989] studied small impoundments across less agricultural regions of the United States and reported sediment organic carbon $(1.9 \% \pm 1.1$, as mass $)$ and assumed a uniform dry bulk density of $1000 \mathrm{~kg} \mathrm{~m}^{3}$. Although bulk density assumptions were close to those we measured in 25 of our impoundments (Table 1 and Figure 4), except in those that were filling with sediment most rapidly, our LOI estimates of sediment OC concentrations were about threefold higher, on average, than those assumed by past studies. Past assumptions about average sediment OC concentration were based on data derived mostly in areas with fairly low terrestrial soil OC [Ritchie et al., 1975; Ritchie et al., 2004; Ritchie and McHenry, 1977], lake sediment OC is known to increase with terrestrial soil OC in the watershed [Ritchie, 1989], and soils in productive agricultural regions are often rich in OC, especially in depositional environments [Ritchie et al., 2004].
Our estimates of sediment OC concentrations were highest in impoundments with small ratios of watershed to lake area (Figure 5). This implies that OC burial in small lakes may be due both to allochthonous inputs from terrestrial soil erosion and to autochthonous $\mathrm{C}$ fixation driven by high nutrient concentrations in these small eutrophic lakes.

[18] Since we did not measure OC directly but calculated it assuming a constant relationship between LOI and OC, a source of error in our estimates could be the assumed relationship between LOI and OC. We chose to calculate OC from LOI assuming that $47 \%$ of LOI is carbon because this is what has been found in analyses of lake and impoundment sediments of similar water chemistry near to those we studied [Dean, 1999; Dean and Gorham, 1976, 1998; Dean, 1974]. Alternatively, if these impoundments have received a more substantial amount of soil from agricultural lands, somewhat more of LOI may be attributable to OC. For example, analyses of agricultural soils in our study area show that OC is an average of $68.2 \%$ of LOI [Konen et al., 2002]. Although ratios of OC to LOI are rarely lower in erodible soils or other sediments than the one we used (0.47) [Craft et al., 1991; Howard, 1965], subsurface forest soils can have ratios of OC to LOI as low as 0.33 [Christensen and Malmros, 1982]. If algal organic material predominates sediment deposition, then ratios of OC to LOI could be as low as 0.4 . Therefore our assumed OC to LOI ratio could lead to errors in estimated sediment OC burial of $+45 \%$ to $-30 \%$.

[19] Rates of sediment OC burial we estimated from measured hydrographic change, measured sediment bulk density, and OC estimated from sediment LOI were orders of magnitude greater than those estimated in natural oligotrophic and eutrophic lakes and much higher than most estimates for reservoirs and impoundments [Mulholland, 1981; Mulholland and Elwood, 1982; Ritchie, 1989]. OC burial rates in oligotrophic lakes were in the range of $10 \mathrm{~g} \mathrm{~m}^{-2} \mathrm{a}^{-1}$ and were about an order of magnitude higher in eutrophic lakes (Table 2 and Figure 7), with small lakes $\left(<10 \mathrm{~km}^{2}\right)$ showing somewhat elevated burial rates. In contrast, more than half of the OC burial estimates in our impoundments were $>1000 \mathrm{~g} \mathrm{~m}^{-2} \mathrm{a}^{-1}$, showing a steep decline in OC burial in larger water bodies. The high rates we observed are not without precedent, however, since some Asian impoundments (see Table 2) bury OC at similar rates [Mulholland, 1981]. Ritchie [1989] found that the $25 \%$ of the impoundments he studied with the highest sediment accumulation rate $(\omega)$ and highest sediment OC content also had $\mathrm{B}>1000 \mathrm{~g} \mathrm{~m}^{-2} \mathrm{a}^{-1}$. Incorrect assumptions concerning OC to LOI ratios in sediments would not alter our interpretation that these impoundments have high rates of $\mathrm{OC}$ burial relative to other aquatic ecosystems (Figure 7). Our high estimates of burial derive principally from high rates of water storage loss due to deposition of high bulk density sediments containing substantial amounts of organic matter.

[20] Our estimates of OC burial in eutrophic lakes were made using uniform methods and are larger than some of those published elsewhere [Dean and Gorham, 1998; Mulholland, 1981; Mulholland and Elwood, 1982; Stallard, 1998]. Many prior estimates have been based on the same data on sediment deposition in impoundments collected by 
Table 2. Carbon Burial Rates in a Variety of Earth's Ecosystems

\begin{tabular}{lcc}
\hline \multicolumn{1}{c}{ Environment ${ }^{\mathrm{a}}$} & $\begin{array}{c}\text { Mean or Median OC } \\
\text { Burial, }^{\mathrm{b}} \mathrm{g} \mathrm{m}^{-2} \mathrm{a}^{-1}\end{array}$ & \multicolumn{1}{c}{ Range } \\
\hline $\begin{array}{l}\text { Eutrophic impoundments } \\
\quad \text { (median, this paper) }\end{array}$ & 2122 & $148-17,392$ \\
$\begin{array}{l}\text { Impoundments (Asia) } \\
\text { Impoundments (central Europe) }\end{array}$ & 980 & $20-3300$ \\
Impoundments (United States) & 465 & $14-1700$ \\
Impoundments (Africa) & 350 & $52-2000$ \\
Marine vegetated habitats & 260 & \\
Small mesoeutrophic lakes & 139 & $83-151$ \\
Abandoned agricultural land & 94 & $11-198$ \\
$\quad$ returning to grassland & 56 & $1.6-110$ \\
Mine spoils returning to forest & & \\
$\quad$ and grassland & 42 & $28-55$ \\
Wetlands and peatlands & 31 & $8-105$ \\
Marine depositional areas & 31 & $17-45$ \\
Abandoned agricultural land & 30 & $21-55$ \\
$\quad$ returning to forests & & \\
Small oligotrophic lakes & 27 & $3-128$ \\
Large mesoeutrophic lakes & 18 & $10-30$ \\
Large oligotrophic lakes & 6 & $2-9$ \\
Boreal forest & 4.9 & $0.8-11.7$ \\
Temperate forest & 4.2 & $0.7-12$ \\
Tropical forest & 2.4 & $2.3-2.4$ \\
Temperate grassland & 2.2 & \\
Tundra & 1.2 & $0.2-2.4$ \\
Temperate desert & 0.8 & \\
\hline
\end{tabular}

${ }^{a}$ Data for lakes and impoundments are from Mulholland and Elwood [1982], data for terrestrial ecosystems including peatlands and wetlands are from Schlesinger [1997], and data for marine ecosystems are from Duarte et al. [2005].

${ }^{\mathrm{b}}$ Where means or medians were not available, the median was approximated as the median of upper and lower limits to the ranges of published values.

a diversity of methods by a variety of U.S. government agencies so the accuracy of these data "varies greatly" [Dendy and Champion, 1978]. Our higher estimates of OC burial derive both from higher estimates of sediment accumulation rates and our direct measurements of dry bulk density and sediment organic matter content. Renwick et al. [2005] have also noted that the historic sediment deposition data [i.e., Dendy and Champion, 1978] seem to yield lower estimates than do modern estimates made with uniform technologies. Further, calculations of OC burial from historical deposition rates have been made with assumed average dry bulk densities instead of more appropriate site-specific values [Dendy and Champion, 1978] and with low values of sediment $\mathrm{OC}$ content extrapolated from other lakes [e.g., Ritchie, 1989]. Because we found that dry bulk density and organic matter content of sediments varied markedly, and were each often greater than assumed in previous studies (e.g., Table 1), this may account for the relatively high estimates of OC burial we found in these impoundments.

[21] The rates of OC burial seen in these eutrophic impoundments were also large when compared to terrestrial OC accumulation. For example, Schlesinger [1997] reported OC burial rates in tundra and forests ranging from only 0.2 to $12 \mathrm{~g} \mathrm{~m}^{-2} \mathrm{a}^{-1}$ (Table 2). Disturbed soils (i.e., via agriculture and mining) returning to natural vegetation accumulate $\mathrm{OC}$ at rates from $21-110 \mathrm{~g} \mathrm{~m}^{-2} \mathrm{a}^{-1}$, while wetlands and peatlands accumulate $8-105 \mathrm{~g} \mathrm{~m}^{-2} \mathrm{a}^{-1}$
(Table 2). OC accumulation in eutrophic, agricultural impoundments is high because they receive allochthonous OC through erosion, enhanced autochthonous OC through nutrient-driven primary productivity, and very high rates of preservation due to nearly continuous sediment anoxia.

[22] These estimates are important for several reasons. First, they indicate that OC burial is likely to be much greater in moderately sized and large impoundments than previously believed, especially where landscapes are disturbed and nutrients abundant. If these data are representative of other regions where impoundments have been created, the average areal OC burial rate in impoundments between 0.01 and $100 \mathrm{~km}^{2}$ may not be quite as high as the rates we observed, but may average about $1000 \mathrm{~g} \mathrm{~m}^{-2} \mathrm{a}^{-1}$; more than double the rate calculated in previous analyses [e.g., Dean and Gorham, 1998; Stallard, 1998]. Although extrapolation of these values to a world scale is speculative, if our analyses are representative, moderately sized impoundments may bury as much as 4 times as much carbon as the world's oceans [Dean and Gorham, 1998]. Although this is a highly provisional estimate for the burial of OC by constructed lakes, the potentially great intensity of OC burial in these systems warrants further refinement and investigation. Appropriate upscaling of these estimates to a global scale will require much more knowledge about the rate of $\mathrm{OC}$ burial in aquatic ecosystems and the factors that control it.

[23] Second, these analyses extend OC burial estimates to the smallest water bodies that dominate the area occupied

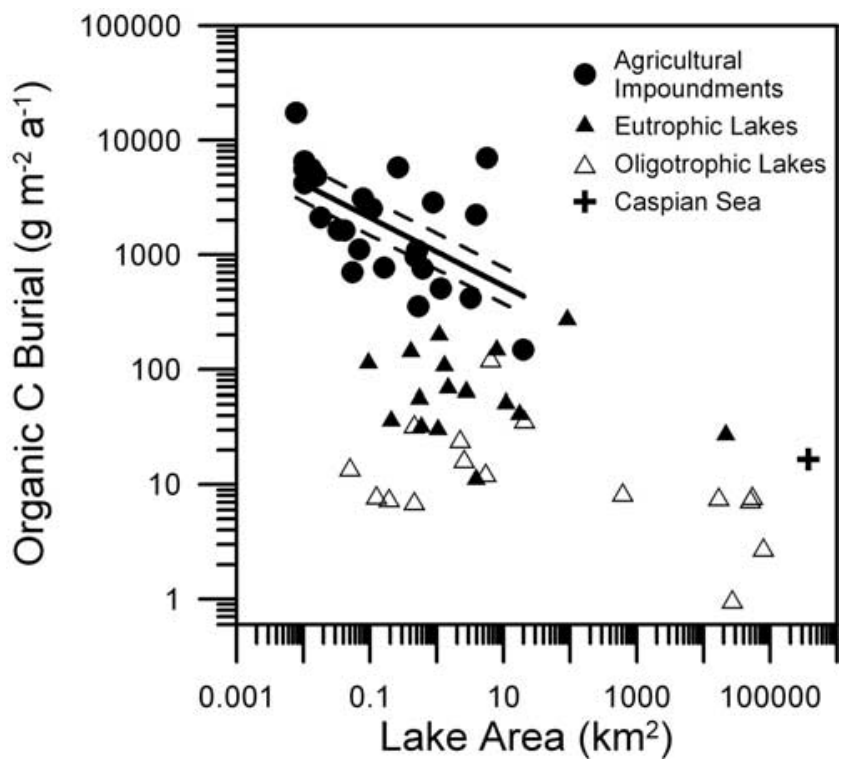

Figure 7. Sediment $\mathrm{OC}$ burial from this study compared to those observed in other analyses. Solid line is fit to the data in Table 1 as described in the legend of Figure 6. Dashed lines indicate the magnitude of variation in this trend that could be due to a plausible range of alternative assumptions of ratios of OC to LOI. Data on eutrophic lakes, oligotrophic lakes, and the Caspian Sea were digitized from Mulholland and Elwood's [1982] Figure 1. 
by natural and impounded waters [Downing et al., 2006]. We have only recently gained some understanding of the number and areal extent of the smallest aquatic ecosystems, especially small impoundments that may have very short lives. Small agricultural impoundments have been shown to occupy $>75,000 \mathrm{~km}^{2}$, globally, and are increasing in abundance [Downing et al., 2006]. If our data are representative of the order of magnitude of OC burial in these small impoundments, these impoundments may bury OC at an average rate of around $2000 \mathrm{~g} \mathrm{~m}^{-2} \mathrm{a}^{-1}$. If global estimates of farm pond abundance are accurate, these smallest impoundments, which have not been considered in prior OC burial estimates, may bury around $150 \mathrm{Tg}$ of OC each year. This is in the range of $33 \%$ of all the carbon delivered to the ocean annually by the world's rivers [Degens et al., 1991; Stallard, 1998] and is near to the estimated annual carbon burial in the world's oceans [Meybeck, 1993; Sundquist, 2003], excluding marine vegetated habitats [Duarte et al., 2004]. Although such upscaling of rates to a global level makes broad assumptions about the prevalence of high-OC burial in small impoundments, it suggests that the role of such water bodies may have been underestimated in the past. The impoundments we studied may be unique in these high rates of apparent OC burial or they may be indicative of a site of global OC burial that had not been previously estimated. More detailed data on OC burial in small aquatic ecosystems are needed to more completely understand the global implications of these small yet carbonactive ecosystems.

[24] Third, burial of OC in the sediments of impoundments includes autochthonous production and therefore may represent an active OC sink that has been heretofore underestimated. The negative relationship between the organic matter content of sediment and the relative size of the watershed to the impoundment area (Figure 5) suggests that the impoundments with the least allochthonous input have the highest sediment organic content. Further, the highest sediment accumulation rates per unit impoundment area were found in the smallest water bodies (equation (1)). Rather than simply being burial points for terrestrial OC, the high rates of primary production in eutrophic impoundments may be responsible for a substantial fraction of the OC burial. That these OC burial rates include both allochthonous and autochthonous inputs is illustrated by rates of annual primary production that rarely exceed $1000 \mathrm{~g} \mathrm{C} \mathrm{m}^{-2} \mathrm{a}^{-1}$, even under very eutrophic conditions [Kalff, 2001; Wetzel, 2001]. The partitioning of OC burial between allochthonous and autochthonous sources is an important question that may be complicated by the confounding of C:N:P stoichiometry in impoundments receiving divergent agricultural signals [Arbuckle and Downing, 2001] and the assumptions of stable isotope analyses where diverse amendments are applied [Post, 2002].

[25] Finally, although decreased delivery of sediments through improved farming practices have been seen elsewhere [Renwick and Andereck, 2006], there is no indication in the data that $\mathrm{OC}$ burial has changed as farm practice has been improved over the last century. Erosion control has been a hallmark of improved farming practice in this agricultural region [Cole et al., 1993], thus OC burial through soil erosion should have declined substantially over the analysis period. Although delays to conveyance of eroded agricultural sediment to lakes and the existence of a weak correlation between lake size and dates of surveys may impede the detection of the influence of improved soil conservation on organic carbon burial, the data do not suggest large differences between early and more recent OC burial. The lack of temporal correlation in OC burial rates suggests that impoundments do not only bury eroded terrestrial OC, but conserve a substantial proportion of atmospheric $\mathrm{C}$ fixation through autochthonous production driven by nutrient losses from intensively managed landscapes. Therefore the major agricultural improvement to practice in this region over the last century, i.e., decreased erosional losses [Yang et al., 2003], may not have led to decreased OC burial because OC burial is driven by both erosion and nutrient-enhanced aquatic eutrophication.

[26] The sediments of eutrophic impoundments appear to be among the most active sites of $\mathrm{C}$ sequestration in the biosphere. Owing to the high rates of autochthonous production, the high rates of input of terrestrial carbon through erosion, and the long-term preservation of organic materials in anaerobic sedimentary environments promoted by high nutrient concentrations, areal rates of OC burial in eutrophic impoundments can be much larger than those observed anywhere else in the biosphere. This finding builds on previous studies showing that ponds and reservoirs can dominate the sediment budgets of large geographical areas [e.g., Renwick et al., 2005] and that erosion and sedimentation can be major OC sinks within the very large watersheds of major river systems [Smith et al., 2005]. Because these are constructed ecosystems, much of the OC sequestered in these lakes met a different fate prior to human development. A recent analysis [Downing et al., 2006] has suggested that impoundments, especially small, low-tech reservoirs, are growing in areal coverage from $1-6 \%$ annually in many agricultural regions around the world (e.g., Europe, India, and the United States). Their increasing area and their extreme ability to sequester OC suggest that they have a growing importance as sinks in the global $\mathrm{C}$ cycle.

\section{Notation \\ A lake area, $\mathrm{km}^{2}$. \\ B sediment burial, $\mathrm{g} \mathrm{m}^{-2} \mathrm{a}^{-1}$. \\ LOI loss on ignition, fraction. \\ $\mathrm{OC}$ organic carbon. \\ $\mathrm{C}$ carbon. \\ $\mathrm{S}$ sediment deposition, $\mathrm{m}^{3} \mathrm{a}^{-1}$. \\ W watershed area, $\mathrm{km}^{2}$. \\ $\Omega$ sediment accumulation, $\mathrm{cm} \mathrm{a}^{-1}$.}

[27] Acknowledgments. This work was conducted as a part of the ITAC Working Group supported by the National Center for Ecological Analysis and Synthesis, a center funded by NSF (grant DEB-94-21535), the University of California at Santa Barbara, and the State of California. We thank Pat Mulholland and Bob Lohnes for sharing data, Rick Cruse for soils information, Jim Raich for information on terrestrial carbon burial, and Bill Renwick, John Melack, Nina Caraco, and an anonymous reviewer for suggestions on the manuscript. Sara Conrad performed the sediment analyses. 


\section{References}

Arbuckle, K. E., and J. A. Downing (2001), The influence of watershed land use on lake N:P in a predominantly agricultural landscape, Limnol. Oceanogr. 46, 970-975.

Calhoun, F. G., et al. (2001), Predicting bulk density of Ohio soils from morphology, genetic principles, and laboratory characterization data, Soil Sci. Soc. Am. J., 65, 811-819.

Christensen, B. T., and P. A. Malmros (1982), Loss-on-ignition and carbon content in a beech forest soil profile, Holarctic Ecol., 5 , $376-380$

Cole, C. V., et al. (1993), Agricultural sources and sinks of carbon, Water Air Soil Pollut., 70, 111-122.

Craft, C. B., et al. (1991), Loss on ignition and Kjeldahl digestion for estimating organic carbon and total nitrogen in estuarine marsh soils: Calibration with dry combustion, Estuaries, 14, 175-179.

Dean, W. E. (1999), The carbon cycle and biogeochemical dynamics in lake sediments, J. Paleolimnol., 21, 375-393.

Dean, W. E., and E. Gorham (1976), Major chemical and mineral components of profundal surface sediments in Minnesota lakes, Limnol. Oceanogr., 21, 259-284

Dean, W. E., and E. Gorham (1998), Magnitude and significance of carbon burial in lakes, reservoirs, and peatlands, Geology, 26, 535-538.

Dean, W. W., Jr. (1974), Determination of carbonate and organic matter in calcareous sediments and sedimentary rocks by loss on ignition: Comparison with other methods, J. Sediment. Petrol., 44, 242-248.

Degens, E. T., et al. (1991), Summary: Biogeochemistry of major world rivers, in Biogeochemistry of Major World Rivers, edited by E. T. Degens et al., pp. 323-347, John Wiley, Hoboken, N. J.

Dendy, F. E. (1968), Sedimentation in the nation's reservoirs, J. Soil Water Conserv., 23, 135-137.

Dendy, F. E., and W. A. Champion (1978), Sediment deposition in U. S reservoirs: Summary of data reported through 1975, USDA Misc. Publ.1362, 84 pp., Agric. Res. Service, U. S. Dept. of Agriculture, Washington, D. C.

Downing, J. A., et al. (1999), Gulf of Mexico hypoxia: Land and sea interactions, Task Force Rep. 134, 44 pp., Council for Agric. Sci. and Technol., Ames, Iowa.

Downing, J. A., et al. (2006), The global abundance and size distribution of lakes, ponds, and impoundments, Limnol. Oceanogr., 51, 2388 2397.

Duarte, C. M., et al. (2004), Major role of marine vegetation on the oceanic carbon cycle, Biogeosci. Discuss., 1, 659-679.

Duarte, C. M., et al. (2005), Major role of marine vegetation on the oceanic carbon cycle, Biogeosciences, 2, 1-8

Einsele, G., et al. (2001), Atmospheric carbon burial in modern lake basins and its significance for the global carbon budget, Global Planet. Change, $30,167-195$

Hallberg, G. R. (1978), Standard procedures for evaluation of Quaternary materials in Iowa, Tech. Info. Ser. 8, 109 pp., Iowa Geol. Surv., Iowa City, Iowa.

Heiri, O., et al. (2001), Loss on ignition as a method for estimating organic and carbonate content in sediments: Reproducibility and comparability of results, J. Paleolimnol., 25, 101-110.

Henderson, C., et al. (1988), The effects of soil water content and bulk density on the compactibility and soil penetration resistance of some western Australian sandy soils, Aust. J. Soil Res., 26, 391-400.

Holeman, J. N. (1975), Procedures used in the Soil Conservation Service to estimate sediment yield, paper presented at Sediment Yield Workshop, United States Dept. of Agriculture, Sedimentation Laboratory, Oxford, Miss., 28-30 November 1972.

Howard, P. J. A. (1965), The carbon-organic matter factor in various soil types, Oikos, 15, 229-236.

Iowa State Planning Board (ISPB) (1935), Report on soundings and borings in the lakes of Iowa, January 1 to March 15, 1935, Iowa State Planning Board, Des Moines, Iowa.

Julien, P. Y. (1995), Erosion and Sedimentation, 280 pp., Cambridge Univ. Press, New York.

Kalff, J. (2001), Limnology: Inland Water Ecosystems, 592 pp., Prentice Hall, Upper Saddle River, N. J.

Konen, M. E., et al. (2002), Equations for predicting soil organic carbon using loss-on-ignition for North Central U, S. soils, Soil Sci. Soc. Am. J., $66,1878-1881$

Lane, E. W., and V. A. Koelzer (1943), Density of sediments deposited in reservoirs, 60 pp., Univ. of Iowa, Iowa City, Iowa.

Laube, K. A. (1991), Sedimentation analysis of Iowa lakes, 122 pp., Iowa State Univ., Ames, Iowa.

McHenry, R. J. (1974), Reservoir sedimentation, Water Resour. Bull., 10 $329-337$.
McNabb, D. H., et al. (2001), Soil wetness and traffic level effects on bulk density and air-filled porosity of compacted boreal soils, Soil Sci. Soc. Am. J., 65, 1238-1247.

Meybeck, M. (1993), Riverine transport of atmospheric carbon: Sources, global typology and budget, Water Air Soil Pollut., 70, 443-463.

Morris, G. L., and J. Fan (1998), Reservoir Sedimentation Handbook: Design and Management of Dams, Reservoirs, and Watersheds for Sustainable Use, 848 pp., McGraw-Hill, New York.

Mulholland, P. J. (1981), Inland aquatic ecosystems and the perturbed global carbon cycle, ORAU/IEA-81-7 (M), Inst. for Energy Anal., Oak Ridge Assoc. Univ., Oak Ridge, Tenn.

Mulholland, P. J., and J. W. Elwood (1982), The role of lake and reservoir sediments as sinks in the perturbed global carbon cycle, Tellus, 34, 490499.

Pacala, S. W., et al. (2001), Consistent land- and atmosphere-based U.S. carbon sink estimates, Science, 292, 2316-2320.

Post, D. M. (2002), Using stable isotopes to estimate trophic position: Models, methods, and assumptions, Ecology, 83, 703-718.

Probst, J. L. (2002), The role of continental erosion and river transports in the global carbon cycle, Geochim. Cosmochim. Acta, 69, A7252005.

Randerson, J. R., et al. (2005), Net ecosystem production: A comprehensive measure of net carbon accumulation by ecosystems, Ecol. Appl., 12, 937-947.

Rausch, D. L., and H. G. Heinnemann (1984), Measurement of reservoir sedimentation, in Erosion and Sediment Yield: Some Methods of Measure ment and Modelling, edited by R. F. Hadley and D. E. Walling, pp. 179200, Geo Books, Norwich, U. K.

Renwick, W. H. (1996), Continent-scale reservoir sedimentation patterns in the United States, in Erosion and Sediment Yield: Global and Regional Perspectives, edited by D. E. Walling and B. W. Webb, pp. 513-522, Int. Assoc. Hydrol. Sci., Gentbrugge, Belgium.

Renwick, W. H., and Z. D. Andereck (2006), Reservoir sedimentation trends in Ohio, USA: Sediment delivery and response to land-use change, in Sediment Dynamics and the Hydromorphology of Fluvial Systems, edited by J. S. Rowan et al., pp. 341-347, Int. Assoc. Hydrol. Sci., Gentbrugge, Belgium.

Renwick, W. H., et al. (2005), The role of impoundments in the sediment budget of the conterminous United States, Geomorphology, 71, 99-111.

Ritchie, J. C. (1989), Carbon content of sediments of small reservoirs, Water Resour. Bull., 25, 301-308.

Ritchie, J. C., and J. R. McHenry (1977), The distribution of Cs-137 in some watersheds in the eastern United States, Health Phys., 32, 101-105.

Ritchie, J. C., et al. (1975), Deposition rates in valleys determined using fallout cesium-137, Geol. Soc. Am. Bull., 86, 1128-1130.

Ritchie, J. C., et al. (2004), Assessing soil organic carbon redistribution with fallout 137cesium, paper presented at 13th International Soil Conservation Organisation Conference, Int. Soil Conserv. Org., Brisbane, Australia.

Schaefer, V. R. (1981), Preliminary investigation of sedimentation in Lake Panorama, Iowa, 100 pp., Iowa State Univ., Ames, Iowa.

Schimel, D. S., et al. (2001), Recent patterns and mechanisms of carbon exchange by terrestrial ecosystems, Nature, 414, 169-172.

Schlesinger, W. H. (1997), Biogeochemistry: An Analysis of Global Change, 588 pp., Elsevier, New York.

Schlotzhauer, S. M., and J. S. Price (1999), Soil water flow dynamics in a managed cutover peat field, Quebec: Field and laboratory investigations, Water Resour. Res., 35, 3675-3683.

Smith, S. V., et al. (2002), Distribution and significance of small, artificial water bodies across the United States landscape, Sci. Total Environ., 299, $21-36$

Smith, S. V., et al. (2005), Fates of eroded soil organic carbon: Mississippi basin case study, Ecol. Appl., 15, 1929-1940.

Spangler, M. G., and R. L. Handy (1982), Soil Engineering, 819 pp. HarperCollins, New York

Stall, J. B. (1981), Estimating reservoir sedimentation rates in the Midwest, in Proceedings of the Symposium on Surface Water Impoundments, edited by H. G. Stefan, pp. 1290-1297, Am. Soc. of Civil Eng., New York.

Stallard, R. F. (1998), Terrestrial sedimentation and the C cycle: Coupling weathering and erosion to carbon storage, Global Biogeochem. Cycles, $12,231-237$

Sundquist, E. T. (2003), The global carbon dioxide budget, Science, 259, 934-935.

Trabelsi, S., et al. (2001), Microwave dielectric sensing of bulk density of granular materials, Meas. Sci. Technol., 12, 2192-2197.

Vanoni, V. A. (1975), Sedimentation Engineering, 745 pp., Am. Soc. of Civil Eng., New York.

Walling, D. E. (1983), The sediment delivery problem, J. Hydrol., 65, 209237. 
Wetzel, R. W. (2001), Limnology: Lake and River Ecosystems, 1006 pp., Elsevier, New York.

Yang, D., et al. (2003), Global potential soil erosion with reference to land use and climate change, Hydrol. Processes, 17, 2913-2928.

J. J. Cole, Institute of Ecosystem Studies, P.O. Box AB, Millbrook, NY 12545 , USA

J. A. Downing, Department of Ecology, Evolution, and Organismal Biology, Iowa State University, 253 Bessey Hall, Ames, IA 50011-1020, USA.

C. M. Duarte, IMEDEA (CSIC-UIB), Miquel Marques 21, E-07190, Esporles, Mallorca, Islas Baleares, Spain.
P. Kortelainen, Finnish Environment Institute, P.O. Box 140, FIN-00251, Helsinki, Finland.

K. A. Laube, Laube Engineering LLC, 6250 West 10th Street, Suite 3, Greeley, CO 80634-8856, USA.

J. J. Middelburg, Centre for Estuarine and Marine Ecology, Netherlands Institute of Ecology (NIOO-KNAW), Koringaweg 7, Yerseke, NL-4401 NT, Netherlands.

Y. T. Prairie, Département des Sciences biologiques, Université du Québec à Montréal, P.O. Box 8888, station Centre-Ville, Montreal, QC, Canada H3C 3P8.

R. G. Striegl, United States Geological Survey, National Research Program, P.O. Box 25046, MS 413, Denver, CO 80225-0046, USA. 